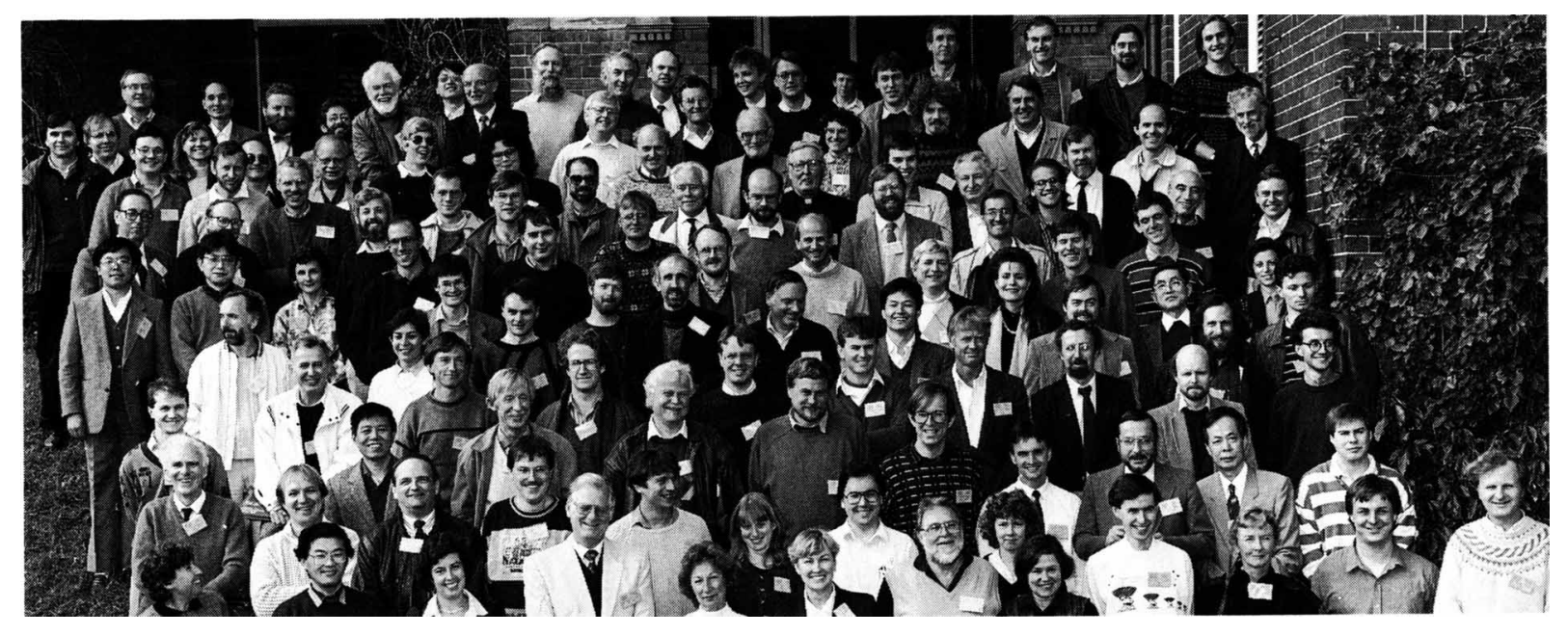

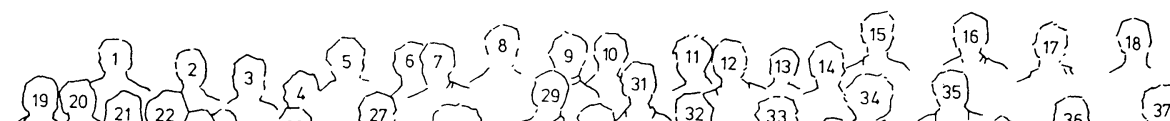

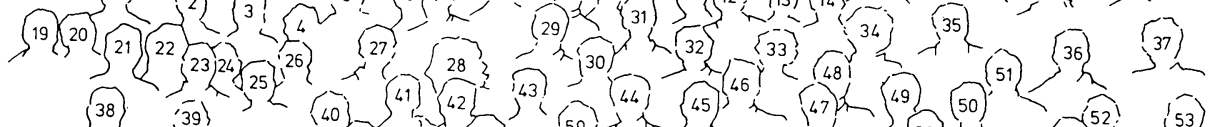

$$
\begin{aligned}
& \text { (38) } 59.59\} \\
& \text { 56) }
\end{aligned}
$$

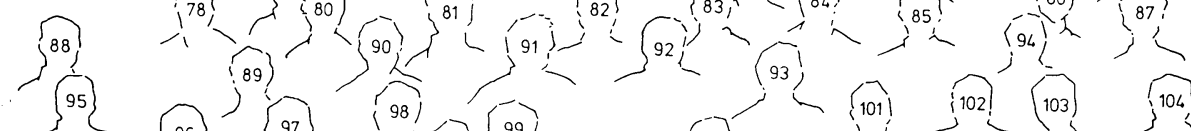

$$
\begin{aligned}
& \text { 395 } \\
& 305\left\{\begin{array}{l}
106 \\
307<
\end{array}\right.
\end{aligned}
$$




\section{GROUP PHOTOGRAPH}

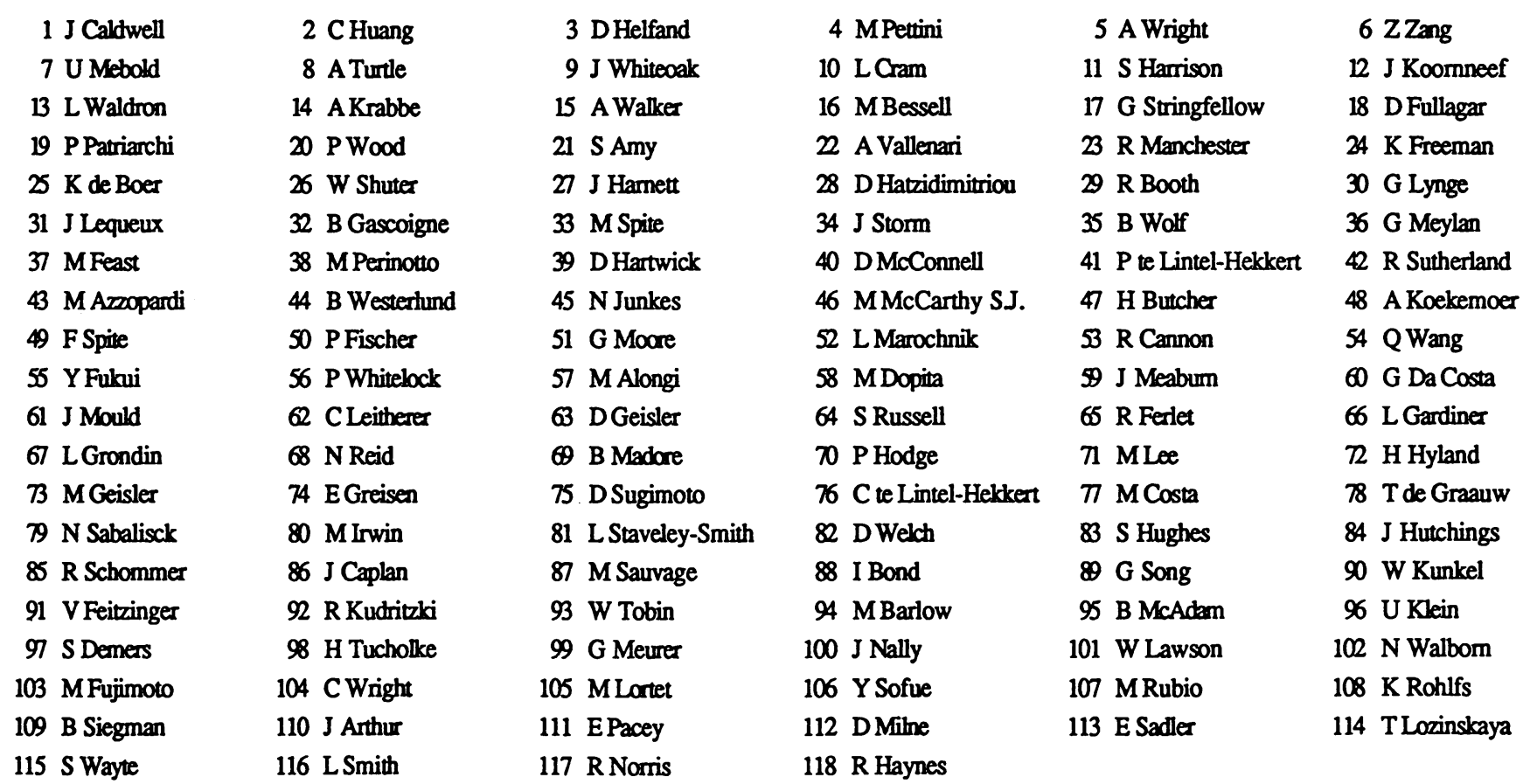

